FACTA UNIVERSITATIS

Series: Physical Education and Sport, Vol. 17, No 1, 2019, pp. 135 - 148

https://doi.org/10.22190/FUPES190415015D

Research article

\title{
PERFORMANCE ANALYSIS AND PROBABILITIES BY GENDER IN JUDO: COMBAT PHASES, TECHNIQUES AND BIOMECHANICAL LEVERS
}

\author{
UDC 796.853.23:015
}

\section{Fábio Dal Bello" ${ }^{1}$ Esteban Aedo-Muñoz ${ }^{2}$, Ciro José Brito ${ }^{3}$, Bianca Miarka ${ }^{4}$}

${ }^{1}$ Research and Graduate Department, University of Santo Tomás, Santiago, Chile ${ }^{2}$ Physical Activity, Sport and Health Sciences Laboratory, University of Santiago, Chile ${ }^{3}$ Physical Education Department, Federal University of Juiz de Fora, Minas Gerais, Brazil

${ }^{4}$ Department of Fights, School of Physical Education and Sport,

Federal University of Rio de Janeiro, Rio de Janeiro, Brazil

\begin{abstract}
The aim of the current study was to compare and verify factors associated with gender in combat phases, techniques and biomechanical leversused during judo matches, and performance probabilities in those same matches. We evaluated highlevel judo athletes from each weight division who qualified for the Olympic Games. 773 male and 638 female bouts were analyzed based on the motor actions during approach, gripping, attack, defense, groundwork and biomechanics of techniques. The current results demonstrated significant differences between male and female bouts in pause frequencies [7(4;12); 9(4;13); $p \leq 0.05]$, and approach with displacements $[1(0$; $6) ; 3(0 ; 9) ; p \leq 0.05]$. Female athletes used higher frequencies of techniques with different biomechanical levers for attacks (i.e. trunk leg lever attempts; waist lever variable attempts, waist lever variable effective and attempts, and maleolo lever effective and attempts; $p \leq 0.05$ ), while men used more variations of gripping (i.e. left collar, left collar and sleeve, both collars, right sleeve, left sleeve and both sleeves; $p \leq 0.05$ ) and groundwork attacks (i.e. Osae-waza, kansetsu-waza and shime-waza attempts; $p \leq 0.05)$. The regression analysis demonstrated that female performance probabilities are associated positively with the use of Osae-waza, Variable/medium length attempted and scored, Arm/foot lever, Minimum lever attempted and scored and negatively with the grip on both collars, while male performance probabilities are associated positively with the use of Variable/medium length scored, Arm/foot lever scored, Minimum lever attempted and negatively with the grip on the right sleeve. The
\end{abstract}

Received April 15, 2019 / Accepted May 31, 2019

Corresponding author: Bianca Miarka

Federal University of Rio de Janeiro, Department of Fights, School of Physical Education and Sport,

Av. Pedro Calmon. $n^{\circ} 550$, Rio de Janeiro, Brazil

Phone: +55 (21) 3938-9600•E-mail: bianca.miarka@ufjf.edu.br 
present data can be applied by coaches and athletes to elaborate the training programs focused on competitive strategies that increase the chances of winning.

Key words: Technical tactical analysis, Judo, Task Performance and Analysis, Martial Arts and Gender

\section{INTRODUCTION}

A judo match includes a complex interaction of open skills, supposedly giving irregular activity and pause periods (Branco et al., 2013). However, a sequential combat system is used to do sequential analysis with five large phases: approach, gripping, attack/defense, groundwork and pause phases (Miarka et al., 2012; Miarka et al., 2014; Miarka et al. 2015). Therefore, during female and male judo competitions, specific actions of each combat phase and pauses are highly diversified and the relationships between these variables collectively characterize an athlete's system of attack or fighting style (Sterkowicz-Przybycien, Miarka, \& Fukuda, 2017).

Recent investigations indicated specific movement patterns that could determine male and female performance, such as the approach and grip attempts, gripping patterns (kumikata), and effective attacks in varying orientations (Franchini, Sterkowicz, Meira, Gomes, \& Tani, 2008; Calmet, Miarka, \& Franchini, 2010; Sterkowicz, Lech, \& Blecharz, 2010; Escobar-Molina, Courel, Franchini, Femia, \& Stanković, 2014; Sterkowicz-Przybycien et al., 2017). For instance, techniques from the same gripping arrangement increase probabilities of resulting in a successful score for both male and female athletes (EscobarMolina et al., 2014; Kajmović \& Rađo, 2014). Preceding reports demonstrated the use of specific tactical elements during the approach phase in male athletes with stances opposite to those of their opponents (kenka-yotsu) to preserve a defensive situation preceding an attack or counter-attack (Boguszewski \& Boguszewska 2006; Franchini et al., 2008; Boguszewski, 2009; Escobar-Molina et al. 2014). Other authors showed that attacks focused on a force couple are used less frequent (39.6\%) than techniques employing a physical lever (60.5\%) (Sterkowicz-Przybycien \& Franchini, 2013).

Notational analysis in judo focuses on identifying movement arrangements, often denoted to as 'performance indicators', in the competitive situation (Brito et al., 2017). Stanković, Cuk, Milošević, \& Stamenković (2015) examined the course of the judo fight at the 2011 World Championship, and diverse motor actions in a total of 959 situations. According to Sterkowicz-Przybycien et al. (2017) motor actions refer to the ability of a male or female athlete to execute specific actions at the correct moment during each combat phase, while quickly adapting to the constantly fluctuating combat environment to the next phase or action. Time-motion analysis has been well-described in judo, verifying match demands (Franchini, Artioli, \& Brito, 2013) and muscle group specific torque production (Sterkowicz-Przybycien \& Franchini 2013; Lech, Chwała, Ambroży, \& Sterkowicz, 2015). An earlier report with an evaluation of sex-specific movement patterns in judo using probabilistic neural networks (Sterkowicz-Przybycien et al., 2017), with accurate biomechanical and statistical analyses, identified that differences between genders do exist; however, it is important to improve this investigation showing possible factors associated with specific tactical arrangements.

A recent investigation recommended that motor action analysis in judo be conducted with consideration for sex differences in each combat phase with a wide range of 
interconnected components (Sterkowicz-Przybycien et al., 2017), such as type of approach (Calmet et al., 2010), type of attacks (Sterkowicz-Przybycien \& Franchini, 2013), defensive actions (Boguszewski, 2011), and groundwork attempts (Miarka et al., 2015). A sequential $\mathrm{T}-\mathrm{T}$ analysis examined each combat phase in both men and women, evaluating the fighting style and movement pattern in men and women (Sterkowicz-Przybycien et al., 2017). Currently, the specific movements of each gender remain unknown; this knowledge is essential for targeting tactical training from male and female motor actions in each combat phase. Consequently, the aim of the present study was to compare and verify factors associated with genders of combat phases, techniques and biomechanical levers used during judo matches. In addition, knowing the performance probabilities of combinations between the different combat phases and their motor actions for victory is essential for the development of tactical training in judo in female and male athletes.

\section{METHODS}

\section{Sample}

The present study considered elite judo athletes from each weight division who qualified for the Olympic Games in 1311 competitive bouts, divided into a male $(\mathrm{n}=773)$, and a female $(n=638)$ group. All bouts were analyzed to complete the motor actions and biomechanical analysis of the applied techniques. In order to guarantee ecological validity and to verify the elite status of the sample, the competitive bouts were analyzed using several publicly available judo video databases, including those provided by the International Judo Federation and the International Olympic Committee. In order to be included, each video had to be of sufficient quality (standard definition 480/60i) and taken from a landscape view of the entire competition area. The competitive bouts were evaluated following previously outlined protocols (Miarka et al., 2012; Miarka et al., 2014; Miarka et al., 2015), from 36 international competitions (IJF, 2012), including the following: Olympic Games (London, 2012), World Championship (Paris, 2011), two editions of World Masters (Almaty, 2012; Baku, 2011), five Grand Slams (Paris, 2011 and 2012; Tokyo, 2011; Rio de Janeiro, 2011 and Moscow, 2011) six Grand Prix's (Düsseldorf, 2011 and 2012; Qingdao, 2011; Amsterdam, 2011; Abu Dhabi, 2011), three Continental Competitions (Asian, Uzbekistan, 2012; American, Montreal, 2012 and European, Chelyabinsk, 2012) and 19 World Cups (Prague, 2011 and 2012; Oberwart, 2011 and 2012; Bucharest, 2011 and 2012; Jeju, 2012; Madrid, 2011 and 2012; Tbilisi, 2011 and 2012; Warsaw, 2011, Tallinn, 2012, Miami, 2012, San Salvador, 2012, Apia, 2012, Buenos Aires, 2012, Lisbon, 2012 and Sofia, 2012). The free computer version of VirtualDub Program 1.8.6(2) was used to fragment and edit images and Frami® software was used to conduct the time-motion analysis; the study was previously approved by the local Ethics and Research Committee.

\section{Analysis of movement with biomechanical and technical-tactical patterns}

The approach phase of combat was subdivided into four categories according to the movement pattern utilized, including a right foot forward stance (Migi-shizen-hontai/Migihontai), a left foot forward stance (Hidari-shizen-hontai/Hidari-hontai), and a frontal stance (Shizen-hontai/Jigo-hontai) (Calmet et al., 2010). The domain attempt was evaluated by the attempt to grip with contact or by the location of the placement of the hands on the 
opponent's uniform (judogi), such as the collar, sleeve or back, and lateral location, right or left, following a previously validated protocol (Calmet et al., 2010).

The attack phase of combat was characterized by the specific biomechanical principles utilized, which were identified by the type of force couple applied or the length and point of application of the moment arm, as outlined by Sterkowicz-Przybycien and Franchini (2013). Throwing techniques that employed a force couple were designated as using: an arm lever, an arm/foot lever, trunk/leg lever, or a trunk/arm lever, while techniques described by the moment arm were designated as minimal length (applied at the opponent's waist), medium length (applied at the opponent's knee), variable length (below the opponent's waist) or maximal length (applied at the opponent's foot/ankle) (Sacripanti, 2012; Sterkowicz-Przybycien \& Franchini, 2013).

Defense in the standing combat phase was categorized by the manner in which the defending athlete changed his/her body position and orientation, right or left (tae-sabaki), in response to an attack and by the use of a counter-attack (Sterkowicz-Przybycien et al., 2017). The groundwork phase of combat was determined by the specific actions conducted, including defensive actions, immobilization/pinning techniques (Osae-waza), chokes (shime-waza) and arm-locks (kansetsu-waza) (Sacripanti, 2012; SterkowiczPrzybycien, \& Franchini, 2013).

\section{Reliability testing}

The reliability measures were assessed through intra-observer and inter-observer testing procedures on motor actions data provided by two experts, with more than ten years of judo experience and university degrees in Physical Education, who analyzed judo matches with FRAMI software. Briefly, for inter-observer agreement, the first expert analyzed 20 performances of athletes and the second expert analyzed the same 20 athletes (Miarka \& Hayashida, 2011). After this procedure, the second expert performed the intra-observer agreement, with the selection of 10 combats (20 athletes) in a randomized order, before repeating the analysis in additional time. The reliability of this software was examined using Cohen's Kappa (Miarka et al., 2016a; Miarka, Fukuda, Del Vecchio, \& Franchini, 2016c). From the distribution for each variable, the following Kappa values and strength of agreement classifications were used: 0.0 to 0.2 , poor; 0.21 to 0.40 , fair; 0.41 to 0.60 , moderate; 0.61 to 0.80 , substantial; 0.81 to 1.00 , almost perfect (Hopkins, 2000). The index and classification of Kappa values of combat/pause phases and T-T indicators used in the present study for Interexpert and Intra-expert measurements were 0.74 and 0.82 , classified as "Strong" and "Almost perfect" for the Approach Phase, 0.45 and 0.96, classified as "Moderate" and "Almost perfect" for the Gripping Phase, 0.52 and 0.97, classified as "Moderate" and "Almost perfect" for the Attack Phase, 0.84 and 0.90, classified as "Almost perfect" and "Almost perfect" for the Defense Phase, 0.90 and 0.97, classified as "Almost perfect" and "Almost perfect" for the Groundwork Phase and 0.91 and 0.99, classified as "Almost perfect" and "Almost perfect" for the Pause Phase, following preceding reports (Miarka et al., 2016a).

\section{Statistical analysis}

Descriptive data are presented as the median, mean [25th percentile; 75th percentile] values, and Mann-Whitney tests were conducted to compare motor actions and biomechanical analysis of technique frequencies between elite male and female judo 
athletes. Effect size was calculated as $r=Z / \sqrt{ } N$, where $\mathrm{Z}$ is derived from the MannWhitney test results and $\mathrm{N}$ is the total number of observations, and interpreted as follows: small $(r=0.10)$, medium $(r=0.30)$ or large $(r=0.50)$ (Cohen, 2003). Furthermore, a logistic regression analysis was used to confirm the effects of technical-tactical actions on the dichotomous variable performance (winning vs. losing). The significance level of $\mathrm{p} \leq$ .05 was used. All analyses were conducted using SPSS 20.0 for Windows.

\section{RESULTS}

The descriptive analysis of total frequencies by each female and male combat phase is presented in Figure 1.
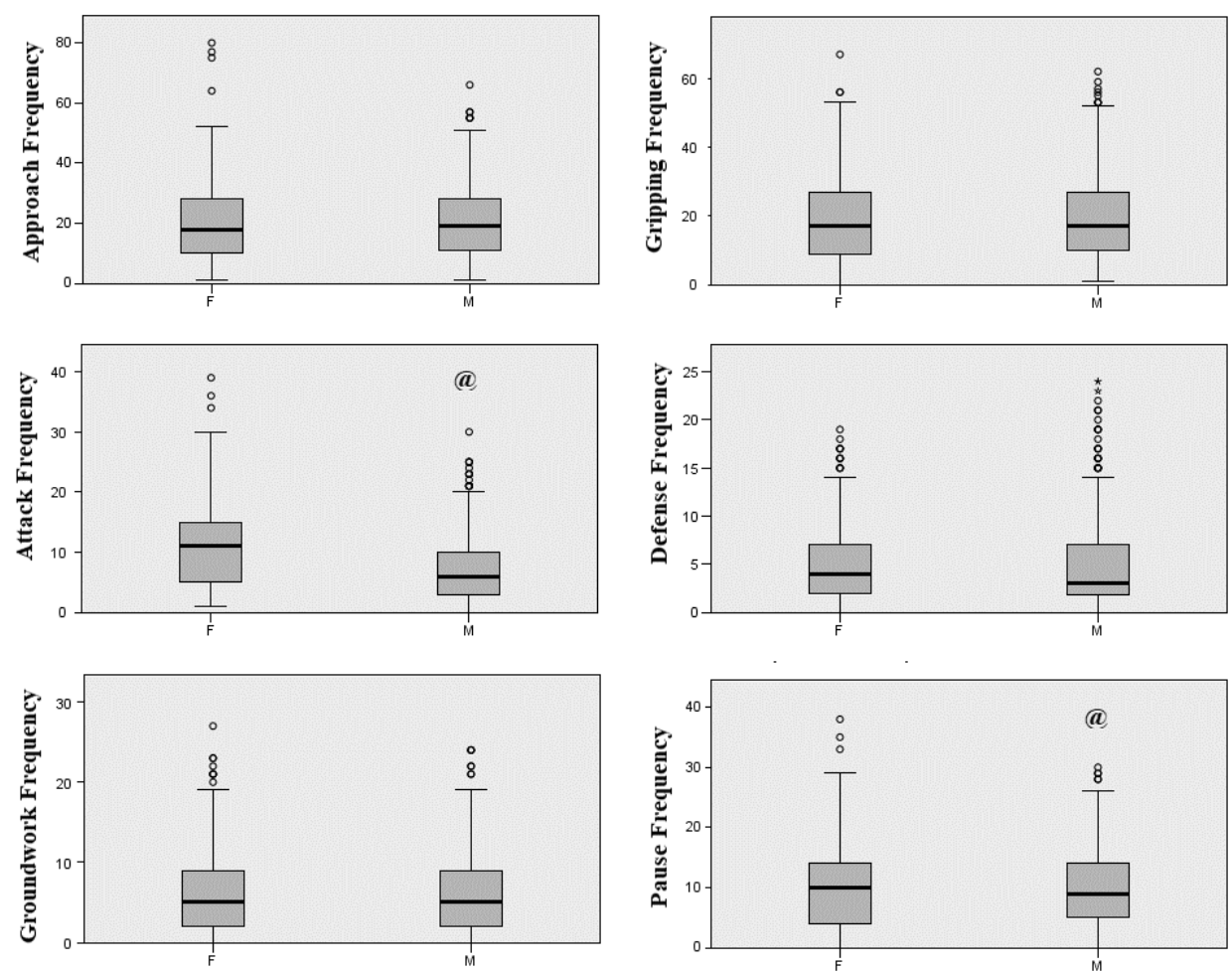

Fig. 1 Frequencies of each combat phase, separated by gender.

$(a=$ significant differences from Female Group, $\mathrm{p} \leq 0.05 . \circ=$ outliers.

The female athletes demonstrated higher Attack frequency ( $U=205462.000 ; p \leq 0.001$, $\mathrm{ES}=0.14)$ and Pause occurrence $(\mathrm{U}=226746.500 ; \mathrm{p}=0.009$, $E S=0.07)$ than the male. No effects were observed between the males and females, when comparing Approach, Gripping, Defense and Groundwork combat phases ( $>0.05$ for all comparisons). 
Descriptive and inferential comparisons of motor actions during the Approach Phase are presented in Table 1.

Table 1 Descriptive and inferential results of motor actions during the Approach Phase by gender

\begin{tabular}{lcccccc}
\hline \multirow{2}{*}{ Approach attempts } & Female & Male & \multicolumn{4}{c}{ Inferences } \\
\cline { 2 - 7 } & Med $(\mathrm{Q} 1 ; \mathrm{Q} 3)(\%)$ & Med $(\mathrm{Q} 1 ; \mathrm{Q} 3)(\%)$ & $\mathrm{U}$ & $\mathrm{Z}$ & Sig. & $\mathrm{ES}$ \\
\hline $\begin{array}{l}\text { Migi-shizen- } \\
\text { hontai/Migi-hontai }\end{array}$ & $18.0(10.0 ; 28.0)^{\mathrm{a}}$ & $8.0(0.0 ; 41.7)$ & 207309 & -5.319 & $\leq .001$ & -0.14 \\
$\begin{array}{l}\text { Hidari-shizen- } \\
\text { hontai/Hidari-hontai }\end{array}$ & $14.3(0.0 ; 47.8)$ & $3.2(0.0 ; 38.5)$ & 242723 & -0.536 & 0.592 & -0.01 \\
$\begin{array}{l}\text { Shizen-hontai/ } \\
\begin{array}{l}\text { Jigo-hontai } \\
\text { Trying to grip }\end{array}\end{array}$ & $4.8(0.0 ; 40.0)$ & $0.0(0.0 ; 20.0)$ & 239162 & -1.027 & 0.304 & -0.03 \\
\hline \multicolumn{4}{c}{$\mathrm{a}=$ significant differences from Male Group, $\leq \leq 0.05$. Sig. Significance. }
\end{tabular}

The female athletes present a high frequency of Hidari-shizen-hontai/Hidari-hontai and Shizen-hontai/Jigo-hontai and a lower frequency of Trying to grip than male athletes ( $p \leq 0.03$ for all comparisons). Descriptive and inferential comparisons of configurations used during gripping attempts are presented in Table 2.

Table 2 Descriptive and inferential results configurations used during gripping attempts by gender

\begin{tabular}{|c|c|c|c|c|c|}
\hline \multirow[b]{2}{*}{ Gripping attempts } & \multirow{2}{*}{$\begin{array}{c}\text { Female } \\
\text { Med (Q1; Q3) } \\
(\%)\end{array}$} & \multirow{2}{*}{$\begin{array}{c}\text { Male } \\
\text { Med (Q1; Q3) } \\
(\%)\end{array}$} & \multicolumn{3}{|c|}{ Inferences } \\
\hline & & & $\mathrm{U}$ & ES & Sig. \\
\hline On the Right Back & $17.0(9.0 ; 27.0)^{\mathrm{a}}$ & $0.0 \quad(0.0 ; 0.0)$ & 23383 & 0.08 & $\leq .001$ \\
\hline On the Right Back and Sleeve & $0.0(0.0 ; 0.0)$ & $0.0 \quad(0.0 ; 4.5)$ & 24303 & 0.02 & 0.56 \\
\hline On the Left Back & $0.0(0.0 ; 3.7)^{\mathrm{a}}$ & $0.0 \quad(0.0 ; 0.0)$ & 23962 & 0.05 & 0.09 \\
\hline On the Left Back and Sleeve & $0.0(0.0 ; 0.0)$ & $0.0 \quad(0.0 ; 7.4)$ & 24233 & 0.02 & 0.507 \\
\hline On the Right Collar & $0.0(0.0 ; 4.5)$ & $7.7(0.0 ; 23.1)$ & 234531 & 0.04 & 0.101 \\
\hline On the Right Collar and Sleeve & $4.7(0.0 ; 18.8)$ & $4.3(0.0 ; 18.2)$ & 23755 & 0.03 & 0.214 \\
\hline On the Left Collar & $7.4(0.0 ; 33.9)^{\mathrm{a}}$ & $6.4(0.0 ; 20.0)$ & 22489 & 0.08 & 0.003 \\
\hline On the Left Collar and Sleeve & $3.9(0.0 ; 18.2)^{\mathrm{a}}$ & $7.1(0.0 ; 21.4)$ & 23083 & 0.06 & 0.033 \\
\hline On the Both Collar & $10.0(0.0 ; 35.7)^{\mathrm{a}}$ & $0.0 \quad(0.0 ; 5.0)$ & 22205 & 0.1 & $\leq .001$ \\
\hline On the Right Sleeve & $0.0(0.0 ; 8.3)^{\mathrm{a}}$ & $3.6(0.0 ; 13.7)$ & 22474 & 0.08 & 0.002 \\
\hline On the Left Sleeve & $0.0(0.0 ; 4.5)^{\mathrm{a}}$ & $3.3(0.0 ; 12.6)$ & 21919 & 0.11 & $\leq .001$ \\
\hline On the Both Sleeve & $0.0(0.0 ; 5.7)^{\mathrm{a}}$ & $0.0(0.0 ; 13.9)$ & 21326 & 0.12 & $\leq .001$ \\
\hline
\end{tabular}

${ }^{\mathrm{a}}=$ significant differences from Male Group, $\mathrm{p} \leq 0.05$. Sig. Significance. 
Male athletes showed a lower frequency of On the Right back $(p \leq 0.001)$, On the Left Collar $(p=0.003)$, On Both Collars $(p \leq 0.001)$, and showed a higher frequency of On the Left Collar and Sleeve $(p=0.003)$, On the Right Sleeve $(p=0.003)$, On the Left Sleeve $(p \leq 0.001)$ and On Both Sleeves $(p \leq 0.001)$. Descriptive and inferential comparisons of the Biomechanics of techniques used during attacks and the Groundwork Phase are presented in Table 3.

Table 3 Descriptive and inferential results of the Biomechanics used during the Attack phase and groundwork actions by gender

\begin{tabular}{lrrrrr}
\hline & \multicolumn{1}{c}{ Female } & \multicolumn{2}{c}{ Male } & \multicolumn{3}{c}{ Inferences } \\
\cline { 2 - 6 } & Med (Q1; Q3) $(\%)$ & Med $(\mathrm{Q} 1 ; \mathrm{Q} 3)(\%)$ & $\mathrm{U}$ & Sig. & ES \\
\hline Biomechanical levers & & & & & \\
\hline Arm and trunk/arm lever & $11.0(5.0 ; 15.0)$ & $33.3(0.0 ; 57.1)$ & 240600 & 0.186 & 0.04 \\
attempted & & & & & \\
Arm/foot lever attempted & $0.0(0.0 ; 0.0)$ & $0.0(0.0 ; 0.0)$ & 231499 & 0.045 & 0.05 \\
Arm/foot lever scored & $23.1(5.3 ; 70.2)$ & $0.0(0.0 ; 0.0)$ & 239647 & 0.058 & 0.05 \\
Minimal length attempted & $0.0(0.0 ; 0.0)$ & $0.0(0.0 ; 16.7)$ & 246136 & 0.937 & 0.00 \\
Trunk/leg lever & $26.7(0.0 ; 100.0)^{\mathrm{a}}$ & $0.0(0.0 ; 0.0)$ & 194965 & $\leq .001$ & 0.19 \\
Trunk/leg lever scored & $26.7(0.0 ; 100.0)$ & $7.1(0.0 ; 33.3)$ & 240451 & 0.056 & 0.05 \\
Variable/ medium length & $8.3(0.0 ; 27.3)^{\mathrm{a}}$ & $0.0(0.0 ; 0.0)$ & 214063 & $\leq .001$ & 0.12 \\
attempts & & & & & \\
Variable/ medium length & $0.0(0.0 ; 0.0)^{\mathrm{a}}$ & $0.0(0.0 ; 23.5)$ & 238014 & 0.011 & 0.07 \\
scored & & & & & \\
Maximal length & $0.0(0.0 ; 7.7)^{\mathrm{a}}$ & $0.0(0.0 ; 0.0)$ & 231238 & 0.022 & 0.06 \\
Maximal length scored & $0.0(0.0 ; 0.0)$ & $0.0(0.0 ; 0.0)$ & 245330 & 0.68 & 0.01 \\
\hline Groundwork actions & & & & & \\
\hline Defensive position on the & $9.7(0.0 ; 27.3)$ & $5.0(2.0 ; 9.0)$ & 241085 & .469 & $-0,02$ \\
ground & & & & & \\
Osae-waza & $5.0(2.0 ; 9.0)^{\mathrm{a}}$ & $0.0(0.0 ; 0.0)$ & 232332 & $\leq .001$ & $-0,13$ \\
Kansetsu-waza & $0.0(0.0 ; 0.0)^{\mathrm{a}}$ & $0.0(0.0 ; 0.0)$ & 242020 & .02 & $-0,06$ \\
Shime-waza & $0.0(0.0 ; 0.0)^{\mathrm{a}}$ & $0.0(0.0 ; 0.0)$ & 241710 & .009 & $-0,07$ \\
\hline Nat Signicand
\end{tabular}

Note: Significant differences are in bold; variable and medium length attempts and arm arm/trunk lever

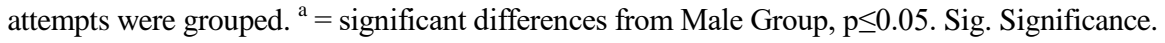

For biomechanical levers, the females showed a higher frequency of Trunk/leg $(p \leq 0.001)$, Variable/medium length attempts $(p \leq 0.001)$, Maximal length $(p=0.022)$ and a lower frequency of Variable/ medium length scored $(p=0.011)$. For Groundwork actions, female athletes showed a higher frequency of Osae-waza $(p \leq 0.001)$. A logistic regression analysis was made to verify factors associated with performance probabilities in female judo combats, which are showed in Table 4. 
Table 4 Performance probabilities of motor actions and combat phases that can increase chances of victory for female judo combats

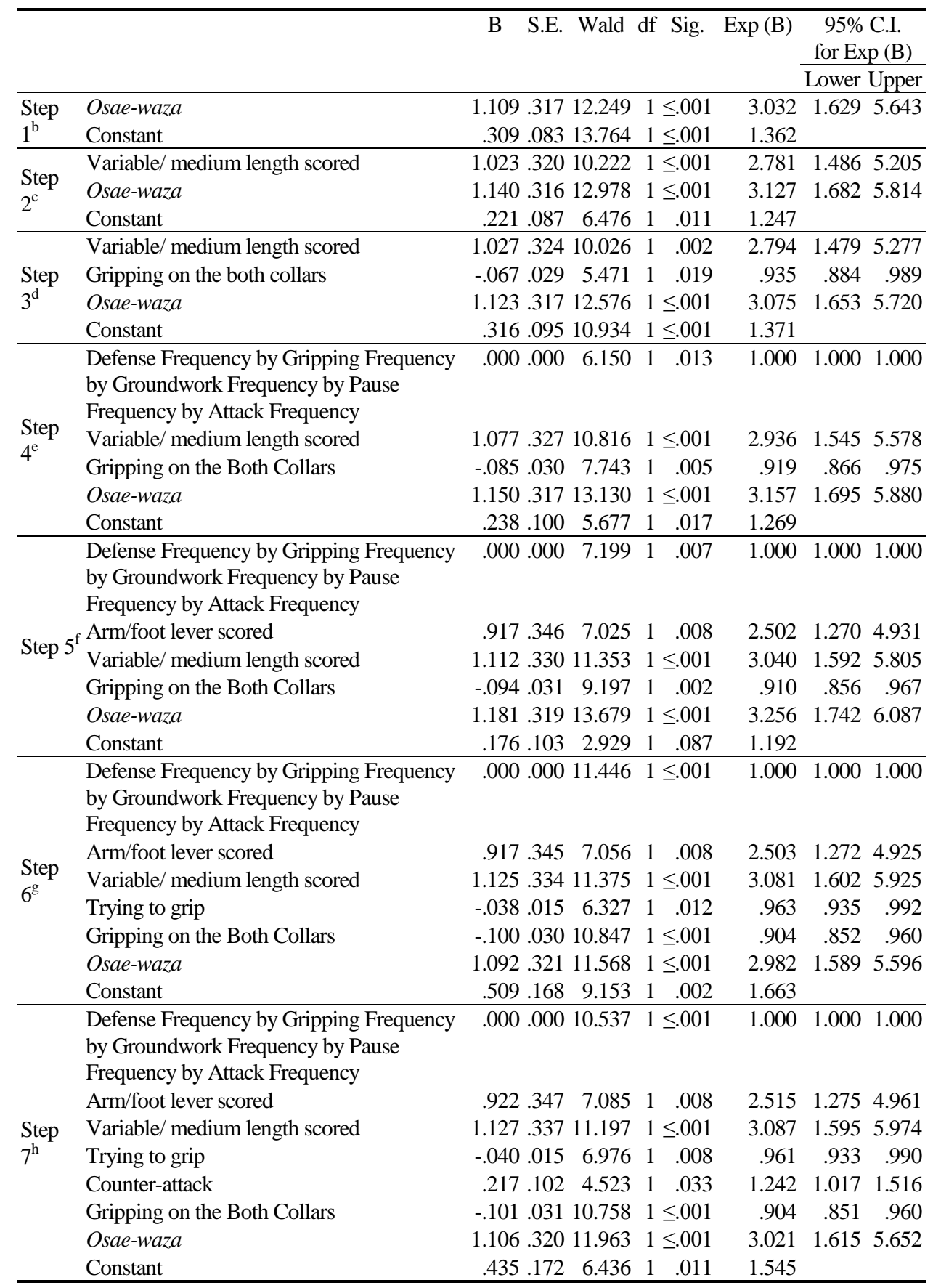


According Table 4, the chance of winning (calculated using ODD) in the $1^{\text {st }}$ step increased $3.2 \%$ with Osae-waza; in the $2^{\text {nd }}$ step, the Osae-waza increased $12.7 \%$, when combined with a Variable/ medium length scored, which increased $79.4 \%$ of the chance to win. After, in the $3^{\text {rd }}$ step, the Osae-waza increased $7.5 \%$, when combined with a Variable/ medium length scored, which an increased $79.4 \%$ chance of winning, while gripping on both collars seems to be negative to the performance, demonstrating a decrease of $6.5 \%$ chance of winning. In the $4^{\text {th }}$ step, using a combination of Attack by Defense by Gripping by Groundwork by Pause Phase will give a neutral probability to win or lose in combat, but this sequence combined with the motor actions Variable/ medium length scored or Osae-waza increases the chance of winning to $93.6 \%$ and $15.7 \%$, respectively. In the $5^{\text {th }}$ step, using the Arm/foot lever scored increased the chance of winning to $50.2 \%$, combined with Osae-waza, which increases it to $25.6 \%$. In the $6^{\text {th }}$ step, using the Arm/foot lever scored increased the chance of winning to 50.2\%, combined with Variable/ medium length scored, with an increased $8.1 \%$ in both affects of Osae-waza, which increases the chance of winning to $98.2 \%$. In the last step, the Arm/foot lever scored increased the chance of winning to $51,5 \%$ followed by a counter-attack, which increased the chance of winning to $24.2 \%$. A logistic regression analysis was made to verify the factors associated with performance probabilities in female judo combats, and is shown in Table 5.

Table 5 Performance probabilities of motor actions and combat phases that can increase chances of victory in male judo combats

\begin{tabular}{llrrrrrrrrr}
\hline & & B & S.E. & Wald & df & Sig. & Exp(B) & \multicolumn{2}{c}{$\begin{array}{c}\text { 95\% C.I. para } \\
\text { EXP(B) }\end{array}$} \\
\cline { 7 - 11 } & & & & & & & & Lower & Upper \\
\hline Step & Variable/ medium length scored & 1.169 & .396 & 8.703 & 1 & .003 & 3.219 & 1.481 & 7.000 \\
$1^{\mathrm{b}}$ & Constant & .389 & .075 & 26.619 & 1 & .000 & 1.475 & & \\
\hline Step & Variable/ medium length scored & 1.232 & .397 & 9.608 & 1 & .002 & 3.428 & 1.573 & 7.469 \\
$2^{\mathrm{c}}$ & Minimal length attempted & .162 & .055 & 8.630 & 1 & .003 & 1.176 & 1.055 & 1.310 \\
& Constant & .242 & .089 & 7.414 & 1 & .006 & 1.274 & & \\
\hline Step & Arm/foot lever scored & .626 & .252 & 6.198 & 1 & .013 & 1.871 & 1.143 & 3.063 \\
$3^{\mathrm{d}}$ & Variable/ medium length scored & 1.252 & .399 & 9.820 & 1 & .002 & 3.497 & 1.598 & 7.650 \\
& Minimal length attempted & .169 & .055 & 9.240 & 1 & .002 & 1.184 & 1.062 & 1.319 \\
& Constant & .175 & .093 & 3.586 & 1 & .058 & 1.192 & & \\
\hline Step & Arm/foot lever scored & .744 & .258 & 8.314 & 1 & .004 & 2.104 & 1.269 & 3.489 \\
$4^{\mathrm{e}}$ & Variable/ medium length scored & 1.250 & .400 & 9.742 & 1 & .002 & 3.490 & 1.592 & 7.652 \\
& Minimal length attempted & .182 & .057 & 10.391 & 1 & .001 & 1.200 & 1.074 & 1.340 \\
& Gripping on the Right Sleeve & -.086 & .032 & 7.347 & 1 & .007 & .917 & .862 & .976 \\
& Constant & .274 & .100 & 7.555 & 1 & .006 & 1.315 & & \\
\hline
\end{tabular}

The chance of winning (calculated using ODD) increased to $21.9 \%$ using the Variable/ medium length scored, in the $2^{\text {nd }}$ step Variable/ medium length scored increased the chance of winning when combined with Minimal length attempted to $42.8 \%$, which increased the chance of winning to $17.6 \%$. In the $3^{\text {rd }}$ step, Variable/ medium length scored increased the chance of winning to 49.7\% when combined with Minimal length attempted, which increased the chance of winning to $18.4 \%$, when combined with the Arm/food lever scored, which increased the chance of winning to $87.1 \%$. In the last step of the regression analysis, gripping on the Right Sleeve reduces the chance of winning to $13.8 \%$. 


\section{DISCUSSION}

The current research aimed to compare and verify factors associated with gender in the combat phases, techniques and biomechanical levers used during judo matches. It was the first time, to the best of our knowledge, that the combination of combat phases and motor actions that lead to victory with the probability of performance for each presented regression model were presented for female and male athletes. The main results demonstrated higher pause frequencies in female athletes than in male athletes and more types of biomechanical levers for attack (trunk leg lever attempts; waist lever variables attempts, waist lever variable attempts and effective, maleolo lever attempts and effective), while men used more variations of gripping (i.e. left collar, left collar and slave, both collars, right sleeve, left sleeve and both sleeves) and groundwork attacks (i.e. Osae-waza, Kansetsuwaza and Shime-waza attempts). These findings agree with the results of previous studies which assumed that sex differences would significantly affect approach, gripping, groundwork, and pause phases, as well as $72 \%$ of the T-T indicators and biomechanical patterns examined during individual combat/pause phases that occur during a competitive judo bout (SterkowiczPrzybycien et al., 2017).

Female bouts had a higher frequency of attacks, possibly resulting in longer pause time, knowledge about effort time and pause, provided important information for the preparation of training sessions (Franchini et al., 2013). As important as as it is to know about the frequency of attacks performed during the effort, it is also crucial to understand the direction and levers applied (Sterkowicz et al., 2010; Miarka et al., 2014). The females showed a higher tendency to take the right handgrip and present a higher volume of Trunk/leg lever techniques, but these attacks did not result in higher scores; however, it is known that higher combat volume can result in competitive advantage since it will result in a penalty toro the opponent (Escobar-Molina et al., 2014), a factor that should be observed by coaches when designing the training and preparing competitive strategies. On the other hand, the male bouts presented homogeneity regarding the analysed variables, and the behavioural aspects determined the techniques preferentially applied during combat (Sterkowicz et al., 2010; Sterkowicz-Przybycien et al., 2017). In summary, our data point to higher diversity in male combat and tendency to apply right-side techniques among the women.

For female athletes, Osae-waza was determined as the winning factor. In fact, the groundwork motor actions are associated with effective actions of $20 \%$ of all attempts to attack during the 2012 Olympic Games (Heinisch et al., 2013). In a previous study, female judo matches presented a greater use of pinning, armlocks, and choking attacks (SterkowiczPrzybycien et al., 2017). In the $2^{\text {nd }}$ step of the female regression analysis, the Osae-waza increased the performance probability when combined with a Variable/medium length scored. This can be explained by the fact that the biomechanical analysis of judo techniques that implicate rotation, such as morote-seoi-nage, and sacrifice throws (sutemi-waza), such as tomoe-nage, involve more time to be applied but less amount of torque and/or velocity before contact with the opponent (uke) (Imamura, Hreljac, Escamilla, Edwards, 2006; Imamura, Iteya, Hreljac, \& Escamilla, 2007; Miarka et al., 2014). However, those techniques with lower extremity (ashi-waza), such as o-soto-gari and de-ashi-haraí, involve high quantities of torque and/or velocity before interaction with the adversary (uke) (Imamura et al., 2006; Imamura et al., 2007). 
Curiously, in female regression analysis, the $3^{\text {rd }}$ step demonstrated that gripping on both collars as a negative determinant performance probability to female athletes, this gripping also decreases the probability to win with Osae-waza, but kept the Variable/ medium length scoreda high chance of winning. The both collar grip is recurrent in defensive situations, as it can maintain high space control over the opponent, but it reduces the imbalance possibilities (kuzushi) and, consequently affects the execution of different techniques and biomechanical actions (Miarka et al., 2016b). There is a range of primary and secondary factors influencing the development of gripping expertise, and gripping appears to be one of the essential characteristics that determine proficiency in competitions (Sterkowicz et al., 2010). In the $4^{\text {th }}$ step of the female regression analysis, using a combination between Attack by Defense by Gripping by Groundwork by Pause Phase will give a neutral probability to win or lose the combat, but this sequence includes the variable/ medium length or Osae-waza increases the chances of winning to $93.6 \%$ and $15.7 \%$, respectively. These results can be explained by the clarity in the decision-making system within this sequence of phases and what to do within each phase (Miarka et al., 2015). This makes the female athlete have a fast and necessary decision making for motor actions in the attack phase (Miarka et al., 2016b). Moreover, the use of sacrifice throws has been described to happen more often in senior than in junior contestants (Boguszewski, 2011) and may be common during tournaments due to greater scoring effectiveness (Sacripanti, 2012).

In the $5^{\text {th }}$ step of the female regression analysis, we observed a high chance $(50.2 \%)$ of winning which increased using Arm/foot lever scored, combined with Osae-waza, possibly since Arm/foot lever scored techniques allow the realization of a fast transition between the standing combat and the groundwork. Often, female athletes perform a self-projection on the opponent as a strategy of establishing the immobilization following the standing attack. In the $6^{\text {th }}$ step of female regression analysis, using a combination between Variable/ medium length scored and Arm/foot lever scored,both increase the chances of winning ( $60 \%$ of the cases positively affecting the Osae-waza). In the last step, Arm/foot lever scored significantly increased the chances of winning (51.5\%) followed by the counter-attack $(24.2 \%)$. These results support the understanding that attacking strategies are a significant factor in the technical improvement of judo athletes (Escobar-Molina et al., 2014).

Regarding male regression analysis and performance probabilities, the men presented decisive results more in association with the biomechanical patterns of the techniques used. According Table 5, previous findings indicated that the attack phase regarding lever arm and force couple are associated with differences among the sexes related to the application of specific throwing techniques (Sterkowicz-Przybycien et al., 2017). Studies reported a predominance of upper extremity actions of male athletes during high level tournaments, but with specific differences in the techniques applied (Sterkowicz, Sacripanti, \& Sterkowicz Przybycien, 2013; Miarka et al., 2016a), while the preceding study observed greater use of the lower extremity techniques in female junior versus senior state/regional level female athletes (Miarka et al., 2014). A potential limitation of the present study is the change from official rule to male combat time that will directly interfere with the frequency of combat phases, since the new regulation time for all men's matches will be four minutes. This also indicates the need for future further research to verify how these changes in regulation affect the combat phases and their respective motor actions. In addition, notational analysis methods are the reliability of the data entry procedure, or the researcher's ability to reproduce the observed value when measurement is repeated. Large variations in the total time, frequency and mean duration of 
combat actions measured during reliability analyses can affect inter-observer consistency (Miarka et al., 2011). The observational-descriptive approach applied in the current study may limit the extrapolation of the findings.

The present results demonstrated the differences between men and women judo athletes and the probability of performance for each movement pattern model presented by a logistic regression analysis. All the models have a straight association with the biomechanical levers used at the moment of attack by the female, but with a greater determination in the male judo bouts. Therefore, analysts and coaches can make extensive use of notational analysis and data collection measures to deliver advantageous feedback about each combat phase while developing systematic methods of movement patterns, focusing on the system of biomechanical levers, use of Osae-waza, avoiding gripping configurations (i.e., on both collars of the female and right sleeve of the male athletes), which negatively influence control over the opponent.

\section{CONCLUSION}

The current research aimed to compare and verify factors associated with gender in combat phases, techniques and biomechanical levers used during judo matches. Regarding gender differences, female judo athletes presented higher pause, trunk leg lever attempts, Variable/medium length attempted and scored, minimum lever attempted and scored, while men used higher frequencies of gripping on the left collar, left collar and slave, both collars, right sleeve, left sleeve and both sleeves, and higher groundwork attacks. Although the women presented a lower frequency of immobilization, this was one of the most determinant variables to increase the probability of victory in female judo competitions, while male athlete's performance probabilities are associated with biomechanical levers used during standing attacks.

\section{REFERENCES}

Boguszewski, D. (2009). Defensive actions of contestants during Polish Judo Championships in the years 2005-2008. Baltic Journal of Health and Physical Activity, 1(2), 111-117.

Boguszewski, D. (2011). Defensive actions of world top judoists. Journal of Human Kinetics, 27, 111-122.

Boguszewski, D., \& Boguszewska, K. (2006). Dynamics of judo contests performed by finalists of European Championships (Rotterdam 2005). Archives of Budo, 2, 40-44.

Branco, B.H.L.M. Massuça, L.V. Andreato, B.F. Marinho, B. Miarka, L. Monteiro, et al. (2013). Association between the rating perceived exertion, heart rate and blood lactate in successive judo fights (randori). Asian Journal of Sports Medicine, 4(2), 125.

Brito, C.J., Miarka, B., de Durana, A.L.D., \& Fukuda, D.H. (2017). Home advantage in Judo: Analysis by the combat phase, penalties and the type of attack. Journal of Human Kinetics, 57(1), 213-220.

Calmet, M., Miarka, B., \& Franchini, E. (2010). Modeling of grasps in judo contests. International Journal of Performance Analysis in Sport, 10(3), 229-240.

Cohen, J. (2003). A power primer. Washington: American Psychological Association.

Escobar-Molina, R., Courel, J., Franchini, E., Femia, P., \& Stanković, N. (2014). The impact of penalties on subsequent attack effectiveness and combat outcome among high elite judo competitors. International Journal of Performance Analysis in Sport, 14(3), 946-954.

Franchini, E., Artioli, G.G., \& Brito, C.J. (2013). Judo combat: time-motion analysis and physiology. International journal of Performance Analysis in Sport, 13(3), 624-641.

Franchini, E., Sterkowicz, S., Meira Jr, C.M., Gomes, F.R.F., \& Tani, G. (2008). Technical variation in a sample of high level judo players. Perceptual and Motor Skills, 106(3), 859-869. 
Heinisch, H.R., Oswald, D., Ultsch, M., Bazynski, M., Birod, \& Büsch, D. (2013). Analyse der Olympischen Spiele $2012 \mathrm{im}$ Judo (Analysis of the 2012 Olympic Games in Judo). Zeit-A Trainingswissenschaft, 19(2), 121-150. In German

Hopkins, W. G. (2000). Measures of reliability in sports medicine and science. Sports Medicine, 30(1), 1-15.

Imamura, R.T., Hreljac, A., Escamilla, R.F., \& Edwards, W.B. (2006). A three-dimensional analysis of the center of mass for three different judo throwing techniques. Journal of Sports Science \& Medicine, 5(CSSI), 122-131.

Imamura, R., Iteya, M., Hreljac, A., \& Escamilla, R. (2007). A kinematic comparison of the judo throw Harai-goshi during competitive and non-competitive conditions. Journal of Sports Science \& Medicine, 6(2), 15-22.

Kajmović, H., \& Rađo, I. (2014). A comparison of gripping Configuration and throwing techniques efficiency index in Judo between male and female judoka during Bosnia and Herzegovina Senior State Championships. International Journal of Performance Analysis in Sport, 14(2), 620-634.

Lech, G., Chwała, W., Ambroży, T., \& Sterkowicz, S. (2015). Muscle torque and its relation to technique, tactics, sports level and age group in judo contestants. Journal of Human Kinetics, 45(1), 167-175.

Miarka, B., Branco, B.H., Vecchio, F.B., Camey, S., \& Franchini, E. (2015). Development and validation of a time-motion judo combat model based on the Markovian Processes. International Journal of Performance Analysis in Sport, 15(1), 315-331.

Miarka, B., Cury, R., Julianetti, R., Battazza, R., Julio, U.F., Calmet, M., et al. (2014). A comparison of timemotion and technical-tactical variables between age groups of female judo matches. Journal of Sports Sciences, 32(16), 1529-1538.

Miarka, B., Del Vecchio, F.B., Julianetti, R., Cury, R., Camey, S., \& Franchini, E. (2016a). Time-motion and tactical analysis of Olympic judo fighters. International Journal of Performance Analysis in Sport, 16(1), 133-142.

Miarka, B., Fukuda, H.D., Heinisch, H.D., Battazza, R., Del Vecchio, F.B., Camey, S., et al. (2016b). Timemotion analysis and decision making in female judo athletes during victory or defeat at Olympic and NonOlympic events: Are combat actions really unpredictable?. International Journal of Performance Analysis in Sport, 16(2), 442-463.

Miarka, B., Fukuda, H. D., Del Vecchio, F. B., \& Franchini, E. (2016c). Discriminant analysis of technicaltactical actions in high-level judo athletes. International Journal of Performance Analysis in Sport, 16(1), 30-39.

Miarka, B., Hayashida, C.R., Julio, U.F., Calmet, M., \& Franchini, E. (2011). Objectivity of FRAMI-software for judo match analysis. International Journal of Performance Analysis in Sport, 11(2), 254-266.

Miarka, B., Panissa, V.L.G., Julio, U.F., Del Vecchio, F.B., Calmet, M., \& Franchini, E. (2012). A comparison of time-motion performance between age groups in judo matches. Journal of Sports Sciences, 30(9), 899-905.

Sacripanti, A. (2012). Biomechanical revision of the principles of Dr. Jigoro Kano's judo kodokan. Medicina Dello Sport, 65(2), 265-281.

Stanković, N., Cuk, S., Milošević, N., \& Stamenković, S. (2015). The course of the judo fight at the 2011 World championship. Facta Universitatis Series Physical Education and Sport, 13 (1), 107-113.

Sterkowicz-Przybycien, K., \& Franchini, E. (2013). Demographic profile of combat sports athletes: A comparative analysis between genders and competitive achievement in London 2012. Archives of Budo, 9(2), 149-159.

Sterkowicz-Przybycień, K., Miarka, B., \& Fukuda, D.H. (2017). Sex and weight category differences in timemotion analysis of elite judo athletes: Implications for assessment and training. Journal of Strength and Conditioning Research, 31(3), 817-825.

Sterkowicz, S., Lech, G., \& Blecharz, J. (2010). Effects of laterality on the technical/tactical behavior in view of the results of judo fights. Archives of Budo, 6(4), 173-177.

Sterkowicz, S.A. Sacripanti, \& Sterkowicz-Przybycien, K. (2013). Techniques frequently used during London Olympic judo tournaments: a biomechanical approach. Available at: https://arxiv.org/ftp/arxiv/papers/1308/1308.0716.pdf 


\section{ANALIZA UČINKA I VEROVATNOĆE PERFORMANSI U DŽUDOU U ODNOSU NA POL: FAZE BORBE, TEHNIKE I BIOMEHANIČKE POLUGE}

Cilj ovog istraživanja bio je da se uporede i potvrde faktori povezani sa fazama džudo meča, upotrebljenim tehnikama, biomehaničkim polugama, verovatnoćom izvođenja meča $i$ polom sportiste. Ocenjivani su sportisti visokog nivoa iz svake težinske divizije koji su se kvalifikovali za Olimpijske igre. Analizirano je 773 muških i 638 ženskih napada tokom prilaza, hvata, napada $i$ odbrane sa biomehaničkog aspekta. Rezultati su pokazali značajne razlike između muških $i$ ženskih napada u frekvencijama pauze [7 (4; 12); 9 (4; 13); $p \leq 0,05]$, prilazu sa pomeranjima [1 (0; 6); 3 (0; 9); $p \leq 0.05]$. Sportistkinje su učestalije koristile tehnike sa različitim biomehaničkim polugama prilikom napada (tj. pokušaje poluga trup-noge, struk, skočni zglob; $p \leq 0.05$ ), dok su sportisti koristili više varijacija hvata ( $t j$. ovratnik, rukav, oba rukava; $p \leq 0.05$ ) i napade na tlu (tj. osaevaza, kansetsu-vaza $i$ shime-vaza pokušaje; $p \leq 0.05$ ). Regresiona analiza pokazala je da su verovatnoće performansi sportiskinja pozitivno povezane sa upotrebom osae-vaza, pokušane $i$ ostvarene srednje dužine, poluge ruka/stopalo, minimalnom pokušanpm i postignutom polugom $i$ negativno sa držanjem okovratnika, dok su verovatnoće performansi sportista pozitivno povezane sa upotrebom ostvarene srednje dužine, ostvarene poluge ruka/stopalo, minimalnom pokušanom polugom $i$ negativno sa hvatom rukava. Aktuelni podaci mogu biti od koristi trenerima $i$ sportistima kako bi se razradili programi obuke usmerene ka takmičarskim strategijama koje povećavaju šanse za pobedom.

Ključne reči: tehničko-taktička analiza, džudo, izvođenje i analiza zadataka, borilačke veštine i pol 